\title{
Get it right the first time
}

\author{
Thomas A. D’Amico, MD

\footnotetext{
From the Division of Thoracic Surgery, Department of Surgery, Duke University Medical Center, Durham, NC. Disclosures: Author has nothing to disclose with regard to commercial support.

Received for publication March 27, 2017; accepted for publication March 28, 2017; available ahead of print April 22, 2017.

Address for reprints: Thomas A. D'Amico, MD, Section of General Thoracic Surgery, Duke University Medical Center, DUMC Box 3496, Duke South, White Zone, Room 3589, Durham, NC 27710 (E-mail: thomas. damico@duke.edu).

J Thorac Cardiovasc Surg 2017;154:650-1

$0022-5223 / \$ 36.00$

Copyright $\odot 2017$ by The American Association for Thoracic Surgery

http://dx.doi.org/10.1016/j.jtcvs.2017.03.126
}

The National Comprehensive Cancer Network (NCCN) Clinical Practice Guidelines in Oncology "document evidence-based, consensus-driven management to ensure that all patients receive preventive, diagnostic, treatment, and supportive services that are most likely to lead to optimal outcomes." ${ }^{1}$ Even when category 1 (high-level) evidence is available, practice variation exists in the United States, leading to inferior care and inferior outcomes. ${ }^{2}$ However, optimal outcomes are most difficult to achieve when high-level evidence does not exist.

In a study from the National Cancer Database, it is concluded that the NCCN guidelines for patients with incompletely resected early-stage non-small cell lung cancer (NSCLC) are not supported, specifically addressing the lack of benefit from postoperative radiation therapy (PORT). ${ }^{3}$ Several issues regarding this study merit further attention.

First, the NCCN NSCLC guidelines recognize the lack of evidence supporting the option of PORT in patients with incompletely resected early-stage NSCLC, and this recommendation is qualified by the Category 2B status (low-level evidence, lack of uniform consensus among panel members). ${ }^{1}$ Second, it should be recognized that the preferred recommendation in the guidelines for patients with incompletely resected early-stage NSCLC is re-resection. ${ }^{4}$ This National Cancer Database study did not analyze outcomes with re-resection, which may be appropriate: Re-resection is not commonly performed in patients with incomplete resection, and the use of re-resection likely represents selection bias. ${ }^{3}$

Third, the group of patients with incompletely resected early-stage NSCLC is heterogeneous and includes those with extensive lymphangitic (but N0) involvement leading to a positive bronchial margin (in whom resection also might fail to achieve R0), those who would not tolerate a larger operation needed to achieve R0 resection, those with incomplete lymph node dissection, and those who received an inferior operation (R1/R2 avoidable). It is unlikely that any analysis would identify whether any of these subgroups might benefit from PORT. More important, Smeltzer and colleagues ${ }^{3}$ should advocate the judicious use of intraoperative frozen section. Re-resection, if selected patients.

\section{References} cessed March 26, 2017.

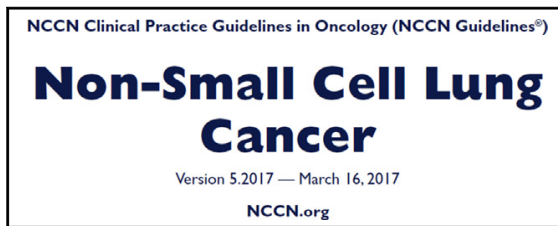

The NCCN guidelines document evidence-based, consensus-driven management.

Central Message

Thoracic surgeons should do everything possible to minimize the incidence of incomplete resection for patients with early-stage lung cancer.

See Article page 661

appropriate, is a more reasonable and feasible option during the primary surgical resection than it would be days to weeks later. As well, in many patients with early-stage NSCLC, sublobar resection is associated with inferior margin status and outcomes. ${ }^{5}$

Adherence to evidence-based treatment guidelines is associated with superior outcomes. When treatment algorithms are based on low-level evidence (as with patients with incompletely resected early-stage NSCLC), patient heterogeneity is often a contributing factor, and therapeutic decision-making is more complex and difficult. For this group of patients, Smeltzer and colleagues ${ }^{3}$ use the National Cancer Database to demonstrate the lack of efficacy of PORT, which has been demonstrated for patients with stage I or II NSCLC. Excellent studies such as this one should be used to inform and improve the NCCN guidelines and to improve evidence-based, consensus-driven decisions and outcomes. Smeltzer and colleagues $^{3}$ recommend that PORT not be used for these patients and that prospective randomized controlled trials should be performed. Until then, however, thoracic surgeons should do everything possible to minimize the incidence of R/R2 resection for patients with early-stage NSCLC, including evidence-based preresection staging, judicious use of intraoperative frozen section, careful consideration of the option of re-resection, and reservation of the use of sublobar resection for appropriately

1. National Comprehensive Cancer Network. NCCN Clinical Practice Guidelines in Oncology. Available at: https://www.ncen.org/professionals/default.aspx. Ac- 
2. Yang CF, Chan DY, Speicher PJ, Gulack BC, Wang X, Hartwig MG, et al. The role of adjuvant therapy in a population-based cohort of patients with early stage small cell lung cancer. J Clin Oncol. 2016;34:1057-64.

3. Smeltzer MP, Lin CC, Kong F-M, Jemal A, Osarogiagbon RU. Survival impact of post-operative therapy modalities according to margin status in non-small cell lung cancer patients in the United States. J Thorac Cardiovasc Surg. 2017;154: 661-72.
4. National Comprehensive Cancer Network. NCCN Clinical Practice Guidelines in Oncology: Non-Small Cell Lung Cancer, version 5. 2017. March 16, 2017. Available at: https://www.nccn.org/professionals/physician_gls/pdf/nscl.pdf. Accessed March 26, 2017.

5. Speicher PJ, Gu L, Gulack BC, Wang X, D’Amico TA, Hartwig MG, et al. Sublobar resection for clinical stage IA non-small cell lung cancer in the United States. Clin Lung Cancer. 2016;17:47-55. 